\title{
Two New Culicoides of the paraensis Species Group (Diptera:Ceratopogonidae) from the Amazonian Region of Peru
}

\author{
Maria Luiza Felippe-Bauer/ ${ }^{+}$, Abraham G Cáceres*, Cristiane S Silva, \\ William Valderrama-Bazan**, Antero Gonzales-Perez***
}

\begin{abstract}
Departamento de Entomologia, Instituto Oswaldo Cruz-Fiocruz, Av. Brasil 4365, 21045-900 Rio de Janeiro, RJ, Brasil
*División de Entomologia, Instituto Nacional de Salud, Ministério de Salud and Instituto de Medicina Tropical "Daniel A. Carrión”, Universidad Nacional Mayor de San Marcos, Lima, Perú **Servicio Nacional de Sanidad Agraria, Ministério de Agricultura, Lima, Perú ***Centro de Salud Bagua Grande, Sub Región de Salud Bagua, Amazonas, Perú
\end{abstract}

Two new species of the Culicoides paraensis species group, C. diversus Felippe-Bauer and C. peruvianus FelippeBauer, are described and illustrated based on female specimens from Amazonian region of Peru. A systematic key, table with numerical characters of females, and distribution of species of the $\mathrm{C}$. paraensis group are given.

Key words: Neotropical bloodsucking midges - Culicoides diversus sp.n. - Culicoides peruvianus sp.n. - Culicoides paraensis group - Amazonian region - Peru

During an epidemiological study of Oropouche in the Departments of Amazonas and Loreto, Peru, specimens of Culicoides were collected while biting humans. These specimens, belonging to the paraensis species group of the subgenus Haematomyidium Goeldi, were given to the first author for determination. The purpose of this work is to describe and illustrate two new species of this species group and provide a key for separation of closely species of the paraensis species group. Culicoides paraensis (Goeldi, 1905) is a widespread species in the New World and its distribution is shown in Fig. 23. The distribution of the other five Neotropical species of this group is presented in Fig. 24.

The terminology used is that employed in Culicoides papers by Wirth and Blanton for Panama (1959), the Amazon Basin (1973), and the West Indies (1974), and the atlas of wing photographs of Neotropical species by Wirth et al. (1988). A summary of information about Oropouche and Mansonellosis transmitted to humans by $C$. paraensis, plus a key and diagnostic characters of the species in the $C$. paraensis group can be found in Wirth and Felippe-Bauer (1989).

\section{KEY TO THE SPECIES OF THE CULICOIDES PARAENSIS} GROUP

1. Second radial cell included in a very dark spot; cell r5 with three or four small pale spots, the two poststigmatic pale spots sometimes fused; subapical pale spot in cell r5 usually transverse, rarely attaining wing margin; cell $\mathrm{m}_{2}$ with only one pale spot distal to level of mediocubital fork; two functional spermathecae with 3rd rudimentary spermatheca and sclerotized ring present; sensilla coeloconica present on flagellomeres 1,6-8, occasionally

${ }^{+}$Corresponding author. Fax: $+5521-2573.4468$. E-mail: mlfbauer@ioc.fiocruz.br

Received 14 July 2003

Accepted 24 November 2003 on flagellomeres 2-5 (subgenus Haematomyidium)

Without the above combination of characters other subgenera of Culicoides

2. Cell $\mathrm{m}_{1}$ with one or two pale spots

.. debilipalpis group

- Cell $\mathrm{m}_{1}$ with three pale spots (paraensis group)

3. Third palpal segment without sensory pit, the sensoria scattered on surface of 3rd segment; spermathecae very unequal sized, the smaller one pyriform.....diversus sp.n.

- Third palpal segment with sensory pit; spermathecae equal or unequal sized..

4. Distal pale spot in cell r5 gradually extending towards subapical pale spot, sometimes spots coalesce; spermathecae equal sized .peruvianus sp.n.

- Distal pale spot distinctly separated from the subapical pale spot; spermathecae unequal sized.

...5

5. Small pale spot present lying anterior to base of mediocubital stem; smaller spermatheca with long threadlike duct, sclerotized ring short and cylindrical; eyes narrowly separated; wing with marginal pale spots large and distinct. .filiductus Wirth

- No pale spot anterior to base of mediocubital stem; smaller spermatheca with duct stouter, not thread like; sclerotized ring, eye separation, and wing spots various

6. Third palpal segment broad (PR 1.7) with pit broad and shallow, rarely deep and opening by a smaller pore; spermathecae very unequal sized; eyes narrowly separated above, contiguous below, the interocular space wedge-shaped; male 9th tergum with short, angulate apicolateral processes; parameres sinuate without ventral lobe; aedeagus with low basal arch .quasiparaensis Clastrier

- Third palpal segment slender to broad with pit deep and narrow, opening by a smaller pore; spermathecae variable; eyes broadly separated; male 9 th tergum with 
slender apicolateral processes; parameres with or without ventral lobe; aedeagus with high basal arch ...7

7.Third palpal segment short and stout (PR 1.7); sclerotized ring short; 3rd rudimentary spermatheca greatly elongate; paramere with definite broad ventral swelling, without elongate lobe ....neoparaensis Tavares \& Souza

- Third palpal segment longer and more slender (PR 2.12.8); sclerotized ring long and curved; 3rd rudimentary spermatheca shorter; paramere uniformly slender in midportion, with elongate lobe paraensis (Goeldi)

Culicoides diversus Felippe-Bauer, new species

(Figs 1, 7-13, 24)

Diagnosis - This large sized species of the paraensis group is distinguished by the following combination of characters: wing length $0.89-0.92 \mathrm{~mm}$; AR 0.64-0.68; flagellum sensillar pattern 1,6-8; mandible with 18 teeth; palpus brown without sensory pit, sensoria scattered on the surface of segment; PR 2.3-2.5; P/H ratio 0.67-0.68; CR 0.59 ; halter pale; two very unequal sized spermathecae, the smaller one pyriform, plus a long rudimentary third and a short sclerotized ring.
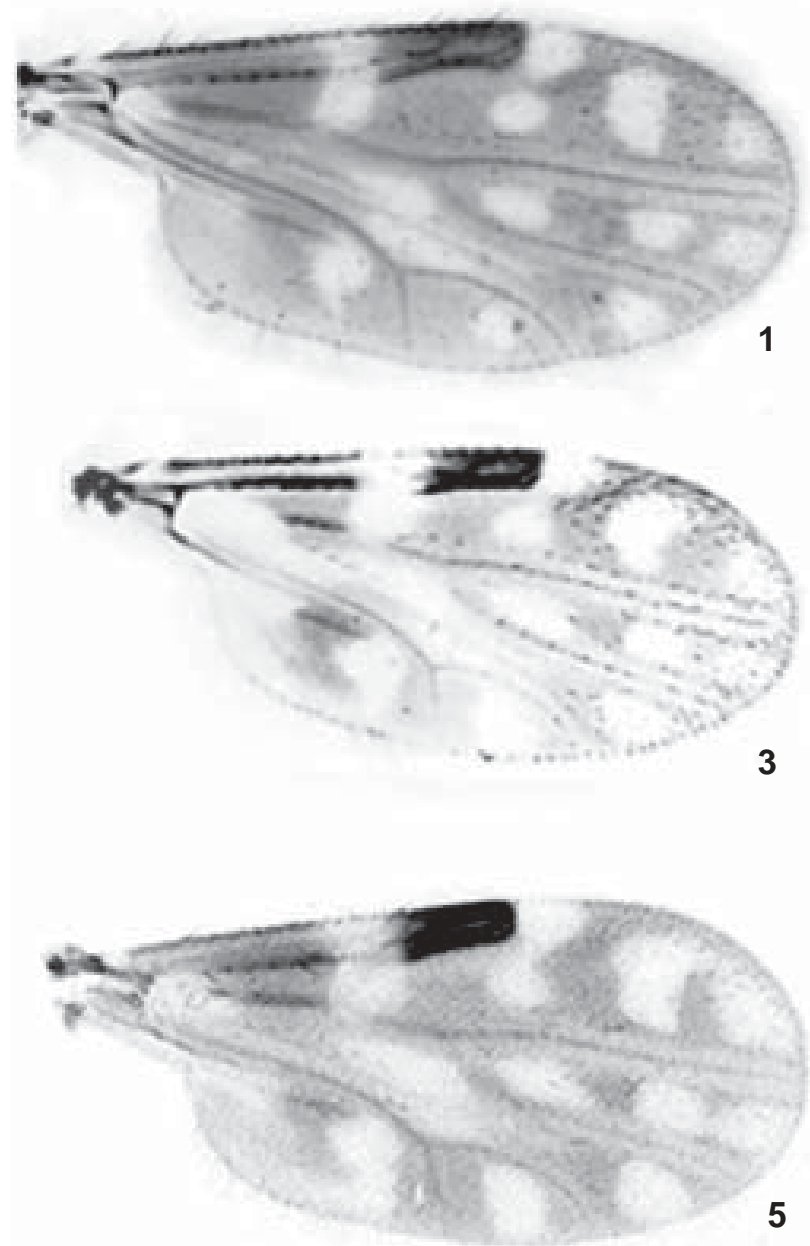
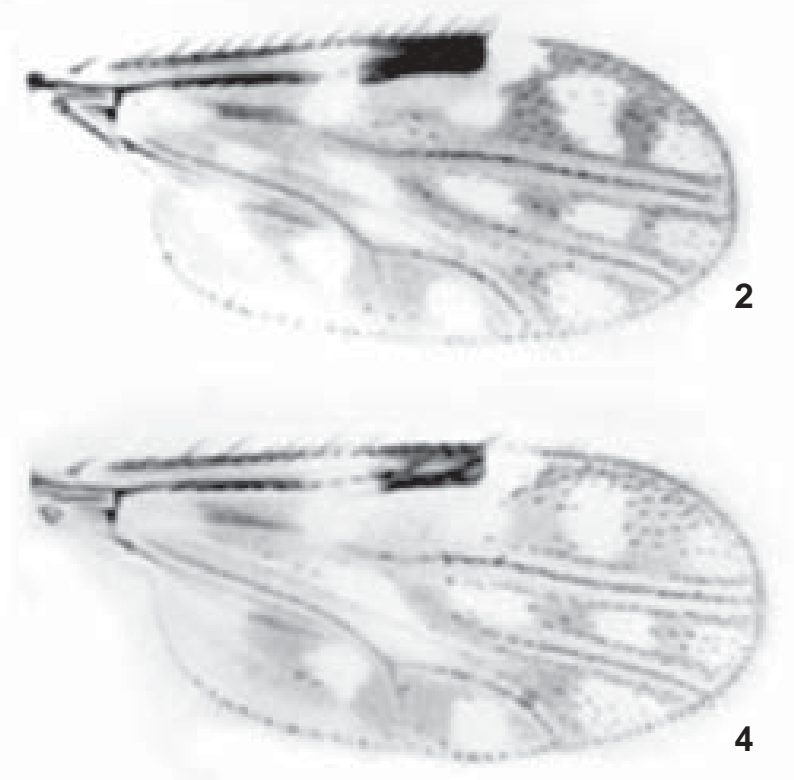

Female - Wing length 0.89-0.92 $(0.91, \mathrm{n}=2)$ mm; breadth $0.45-0.47(0.46, \mathrm{n}=2) \mathrm{mm}$.

Head - Brown. Eyes (Fig. 7) pubescent, broadly separated by distance of 1.0-1.5 ommatidia. Flagellum (Fig. 12) brown, with proximal $2 / 3$ of flagellomeres $2-6$, paler; flagellomeres with means of lengths of 48-43-43-43-43-45-43-43-37-3740-40-72 $\mu \mathrm{m}(\mathrm{n}=2)$; antennal ratio 0.64-0.68 (0.66, $\mathrm{n}=2)$; sensilla coeloconica on flagellomeres $1,6-8$, two on 1, 6-7, three on 8. Palpus (Fig. 8) brown; lengths of segments of 13-40-61-19-19 $\mu \mathrm{m}$; 3rd segment moderately swollen, without sensory pit, sensoria scattered on the surface of segment; palpal ratio 2.3-2.5 $(2.4, \mathrm{n}=2)$. Proboscis short; $\mathrm{P} / \mathrm{H}$ ratio $0.67-0.68(0.67, \mathrm{n}=2)$; mandible with 18 teeth.

Thorax - Brown; without definite pattern in slide mounted specimens. Legs (Fig. 10) mostly brown; fore, mid femora with subapical, tibiae with subbasal pale bands; hind tibia apically pale; hind tibial comb (Fig. 9) with four spines, the two nearest spur longest. Tarsi (Fig. 11) pale, first tarsomere darkest. Wing (Fig. 1) with pattern typical of paraensis group: cell r5 with four small separated spots, two poststigmatic pale spots well separated, the posterior one located slightly proximad of the other, subapical

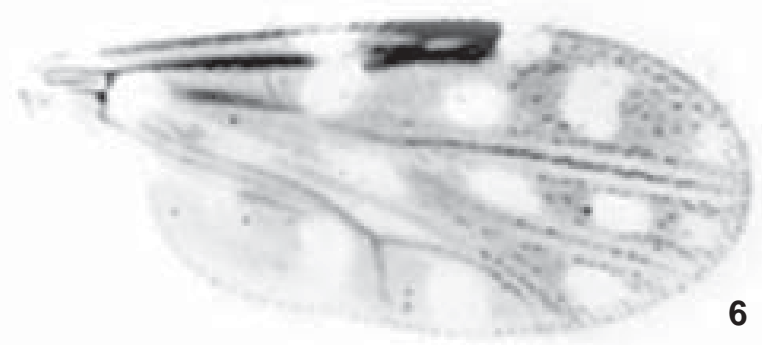

Photographs of female wings of Culicoides of the paraensis group. Fig. 1: C. diversus. Fig. 2: C. filiductus. Fig. 3: C. neoparaensis. Fig. 4: C. paraensis. Fig. 5: C. peruvianus. Fig. 6: C. quasiparaensis 
spot slightly elongated, narrow not reaching costal and an apical small spot; a narrow pale spot over $\mathrm{r}-\mathrm{m}$ crossvein extending from vein $\mathrm{M}$ to costal margin; cell $\mathrm{m}_{1}$ with three rounded spots, distal one near wing margin; cell $\mathrm{m}_{2}$ with three spots, one proximal to medial fork, 2nd one distal to mediocubital fork, 3rd spot rounded, in distal part of cell at wing margin; cell $\mathrm{m}_{4}$ with small, round, pale spot near wing margin; anal cell with one pale spot anterior of mediocubital fork, not reaching wing margin; base of wing without pale spot; veins $\mathrm{M}_{1}$ and $\mathrm{M}_{2}, \mathrm{M}_{3+4}$ and $\mathrm{Cu}_{1}$ dark; macrotrichia sparse on distal half of wing, a few in base of cell $\mathrm{m}_{2}$ and anal cell; second radial cell with distinct lumen; costal ratio $0.59(\mathrm{n}=2)$. Halter pale, base of knob brownish. Abdomen - Brown. Two unequal sized spermathecae (Fig.
13), larger ovoid with long, stout neck, smaller pyriform with long, slender neck, measuring 0.048 by $0.043 \mathrm{~mm}$ and 0.037 by $0.021 \mathrm{~mm}(\mathrm{n}=2)$ respectively; long rudimentary 3rd spermatheca and short sclerotized ring also present. Male - Unknown.

Distribution (Fig. 24) - Peru ( Department of Loreto).

Types - Holotype \%(Dip.Cer.378), paratype + (Dip.Cer. 379). Fundo Majambo, Distrito de Yurimaguas, Provincia de Alto Amazonas, Departamento de Loreto, PERU, 02.III. 2001, Augusto R. Garcia col., biting human. Deposited in Instituto Oswaldo Cruz, Rio de Janeiro, Brazil.

Etymology - The specific name is based on this new species obvious differences from other species of the paraensis group.
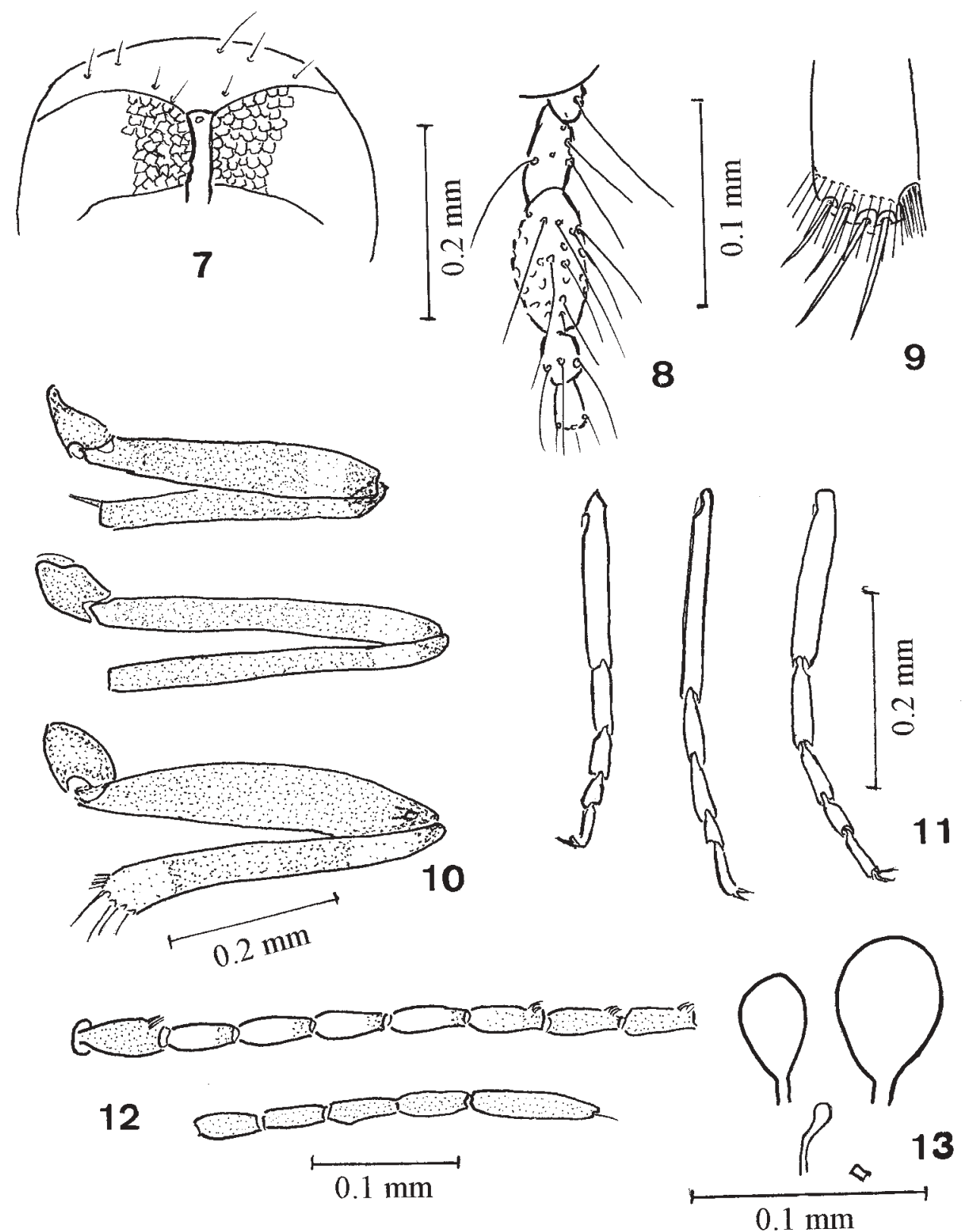

Culicoides diversus sp.n., female. Fig. 7: dorsal portion of head capsule, in anterior view. Fig. 8: palpus. Fig. 9: hind tibial comb. Fig. 10: legs (top to bottom) fore, mid, and hind. Fig. 11: tarsi (left to right) fore, mid, and hind. Fig. 12: antenna. Fig. 13: spermathecae 
Discussion - C. diversus is a typical member of the subgenus Haematomyidium and as outlined in the key and in the Table, may be distinguished from the other species of the paraensis group by its slightly longer wing, small antennal and $\mathrm{P} / \mathrm{H}$ ratio, by the absence of a sensory pit on the 3rd palpal segment with sensoria scattered on the surface of the segment and the very unequal sized spermathecae with the smaller one pyriform.
Culicoides peruvianus Felippe-Bauer, new species

(Figs 5, 14-22, 24)

Diagnosis - This new species of the paraensis group is distinguished by the following combination of characters: wing length $0.73-0.86 \mathrm{~mm}$; AR 0.68-0.78; sensillar pattern 1,6-8; mandible with 18 teeth; palpus brown with sensory pit; PR 2.0-2.4; P/H ratio 0.74-0.90; CR 0.53-0.60; halter pale; two sub-spherical, equal sized spermathecae, plus a

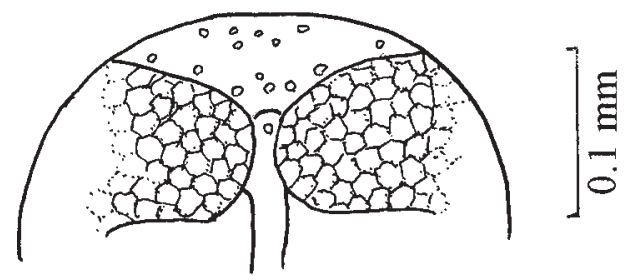

14
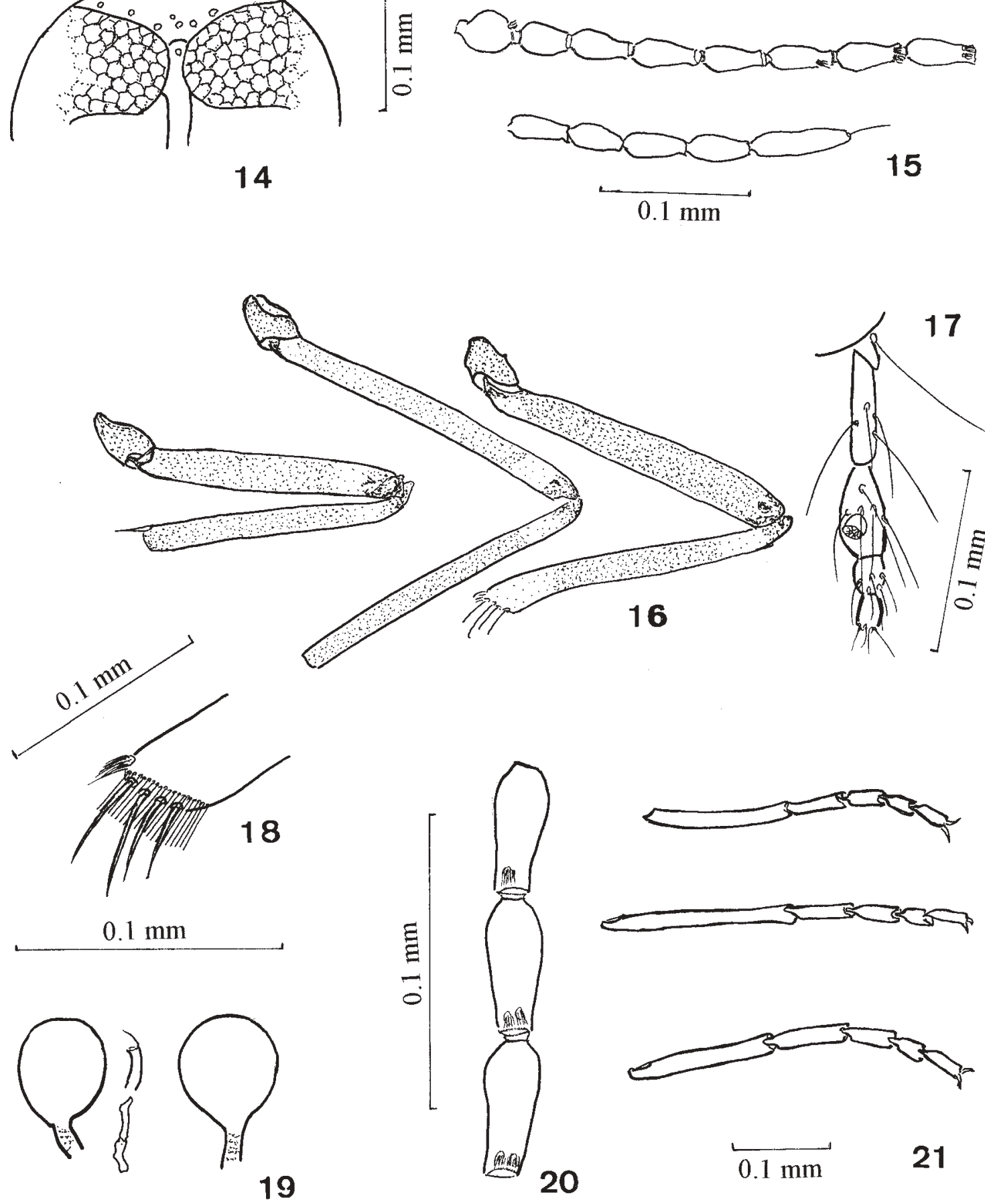

Culicoides peruvianus sp.n., female. Fig. 14: dorsal portion of head capsule, in anterior view. Fig. 15: antenna. Fig. 16: legs (left to right) fore, mid, and hind. Fig. 17: palpus. Fig. 18: hind tibial comb. Fig. 19: spermathecae. Fig. 20: flagellomeres 6-8. Fig. 21: tarsi (top to bottom) fore, mid, and hind 
TABLE

Mean values of numerical characters of females of the Culicoides paraensis group

\begin{tabular}{lcccccc}
\hline Species & $\begin{array}{c}\text { Wing length } \\
(\mathrm{mm})\end{array}$ & $\begin{array}{c}\text { Costal } \\
\text { ratio }\end{array}$ & $\begin{array}{c}\text { Antennal } \\
\text { ratio }\end{array}$ & $\begin{array}{c}\text { Antennal sensillar } \\
\text { pattern }\end{array}$ & $\begin{array}{c}\text { Palpal } \\
\text { ratio }\end{array}$ & $\begin{array}{c}\text { P/H } \\
\text { ratio }\end{array}$ \\
\hline diversus & 0.91 & 0.59 & 0.66 & $1,6-8$ & 2.4 & 0.67 \\
filiductus & 0.87 & 0.60 & 0.72 & $1,6-8$ & 2.8 & 0.73 \\
neoparaensis & 0.90 & 0.62 & 0.86 & $1,(5), 6-8$ & 1.7 & 0.71 \\
paraensis & 0.78 & 0.59 & 0.77 & $1,6-8$ & 2.1 & 0.82 \\
peruvianus & 0.80 & 0.56 & 0.73 & $1,6-8$ & 1.7 & 0.84 \\
quasiparaensis & 0.83 & 0.61 & 0.80 & $1,6-8$ & & 0.75 \\
\hline
\end{tabular}
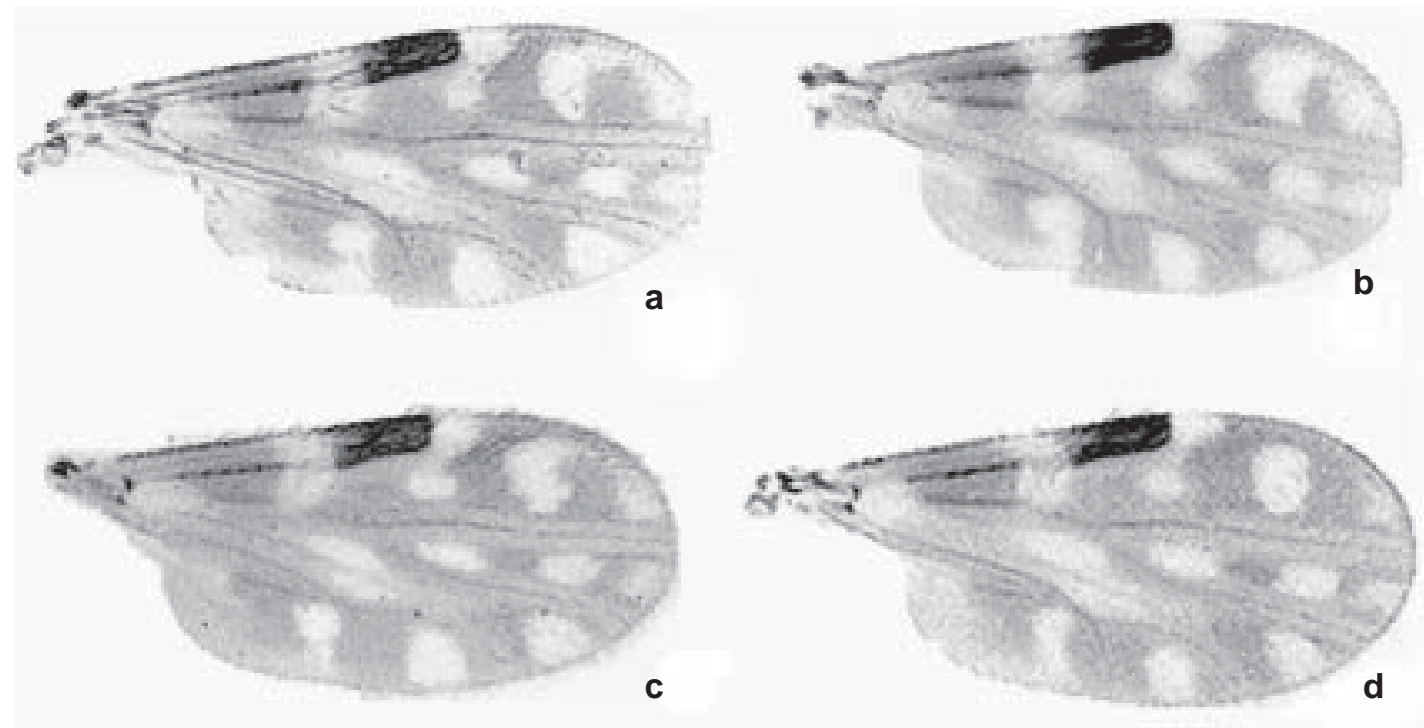

Fig. 22 a-d: variation in the wing pattern of Culicoides peruvianus sp.n.

long rudimentary third and sclerotized ring.

Female - Wing length $0.73-0.86(0.80, \mathrm{n}=16) \mathrm{mm}$; breadth $0.38-0.43(0.42, \mathrm{n}=16) \mathrm{mm}$.

Head - Brown. Eyes (Fig. 14) pubescent, separated by distance of one ommatidia. Flagellum (Fig. 15) brown, flagellomeres with means of lengths of 35-27-32-35-35-3737-37-35-35-37-37-59 $\mu \mathrm{m}(\mathrm{n}=16)$; antennal ratio 0.68-0.78 $(0.73, \mathrm{n}=12)$; sensilla coeloconica present on flagellomeres 1,6-8, two, rarely one on six (Fig. 20). Palpus (Fig. 17) brown; lengths of segments 16-42-45-19-21 $\mu \mathrm{m}$; 3rd segment slightly swollen with small, deep, sensory pit; palpal ratio 2.0-2.4 (2.1, $\mathrm{n}=14)$. Proboscis brown, moderately long; $\mathrm{P} / \mathrm{H}$ ratio $0.74-0.90(0.84, \mathrm{n}=16)$; mandible with 18 teeth.

Thorax - Brown; without definite pattern in slide mounted specimens. Legs (Fig. 16) mostly brown; fore, mid femora with subapical, tibiae with subbasal pale bands; hind tibia apically pale; hind tibial comb (Fig. 18) with four spines, the two nearest spur longest. Tarsi (Fig. 21) pale, first tarsomere darkest. Wing (Figs 5, 22) with pattern typical for paraensis group: cell $\mathrm{r} 5$ with four spots, two poststigmatic pale spots well separated, the posterior one located slightly proximad of the other, subapical spot large, often crescent-shaped, connected to apical large pale spot (Fig. 22 a,b) or the subapical pale spot can be only slightly connected to apical spot (Fig. 22 c), or, well separated from it (Fig. $22 \mathrm{~d}$ ); a narrow pale spot over r-m crossvein extending from vein $\mathrm{M}$ to costal margin; cell $\mathrm{m}_{1}$ with three rounded spots, distal one near wing margin, sometimes the two distal pale spots are connected (Fig. 22 b); cell $\mathrm{m}_{2}$ with three spots, one proximal to medial fork, 2nd one distal to mediocubital fork, 3rd spot rounded, in distal part of cell at wing margin; cell $\mathrm{m}_{4}$ with round pale spot near wing margin; anal cell with one pale spot anterior of mediocubital fork, reaching wing margin; base of wing with pale spot, extending from arculus to anal cell (Fig. 22 $\mathrm{a}, \mathrm{b}, \mathrm{d}$ ); veins $\mathrm{M}_{1}$ and $\mathrm{M}_{2}, \mathrm{M}_{3+4}$ and $\mathrm{Cu}_{1}$ dark; macrotrichia sparse on distal half of wing; second radial cell with distinct lumen; costal ratio 0.53-0.60 $(0.56, \mathrm{n}=16)$. Halter pale.

Abdomen - Brown. Two sub-spherical, equal sized spermathecae (Fig. 19), measuring $0.037(0.035-0.043, \mathrm{n}=11)$ by $0.029(0.027-0.032, \mathrm{n}=11) \mathrm{mm}$, with long, stout, sclerotized neck $(0.011 \mathrm{~mm})$; long rudimentary third $(0.032 \mathrm{~mm})$ and sclerotized ring present.

Male - Unknown.

Distribution (Fig. 24) - Peru (Department of Amazonas). Types - Holotype 9 , San Antonio, Distrito de Cajaruro, Provincia de Utcubamba, Departamento de Amazonas, PERU, 22.IV.2001, A. Gonzales-Perez col., biting human. Paratypes $ㅇ$ as follows: 5 우 온 same data as holotype; 10 우, same data as holotype except 15.VIII.2000, 
13.V.2001, 05.VI.2001, 14.VII.2001 and 22.IX.2001; 1 우, Platana, Distrito de Cumba, Provincia de Utcubamba, Departamento de Amazonas, PERU, 30-31.I.2001, A.G.Caceres col., CDC light trap; 2 ㅇ ㅇ Yungasuyo, Distrito de Lonya Grande, Provincia de Utcubamba, Departamento de Amazonas, PERU, VII.2001, A. Gonzales-Perez col., biting human; 20 우 + Aserradero, Distrito de Jamalca, Provincia de Utcubamba, Departamento de Amazonas, PERU, 01.V.2001, 13.V.2001, 04.VI.2001, 05.VI.2001, 16.VII.2001, 14.VIII.2001 and 16.IX.2001, A. Gonzales-
Perez col., biting human [Holotype (Dip.Cer.380) and 32 paratypes (Dip.Cer.381-412) deposited in Instituto Oswaldo Cruz (IOC), Rio de Janeiro, Brazil; 3 ㅇ s same locality as holotype in Faculdade de Saúde Pública, Universidade de São Paulo, São Paulo, Brazil and 3 ㅇ ㅇ (2 from San Antonio and 1 from Aserradero) deposited in Museo de La Plata, Argentina].

Additional material examined - After determination of the type material we have received additional specimens, preserved in alcohol $70 \%$. These 273 ㅇ $q$ were deposited

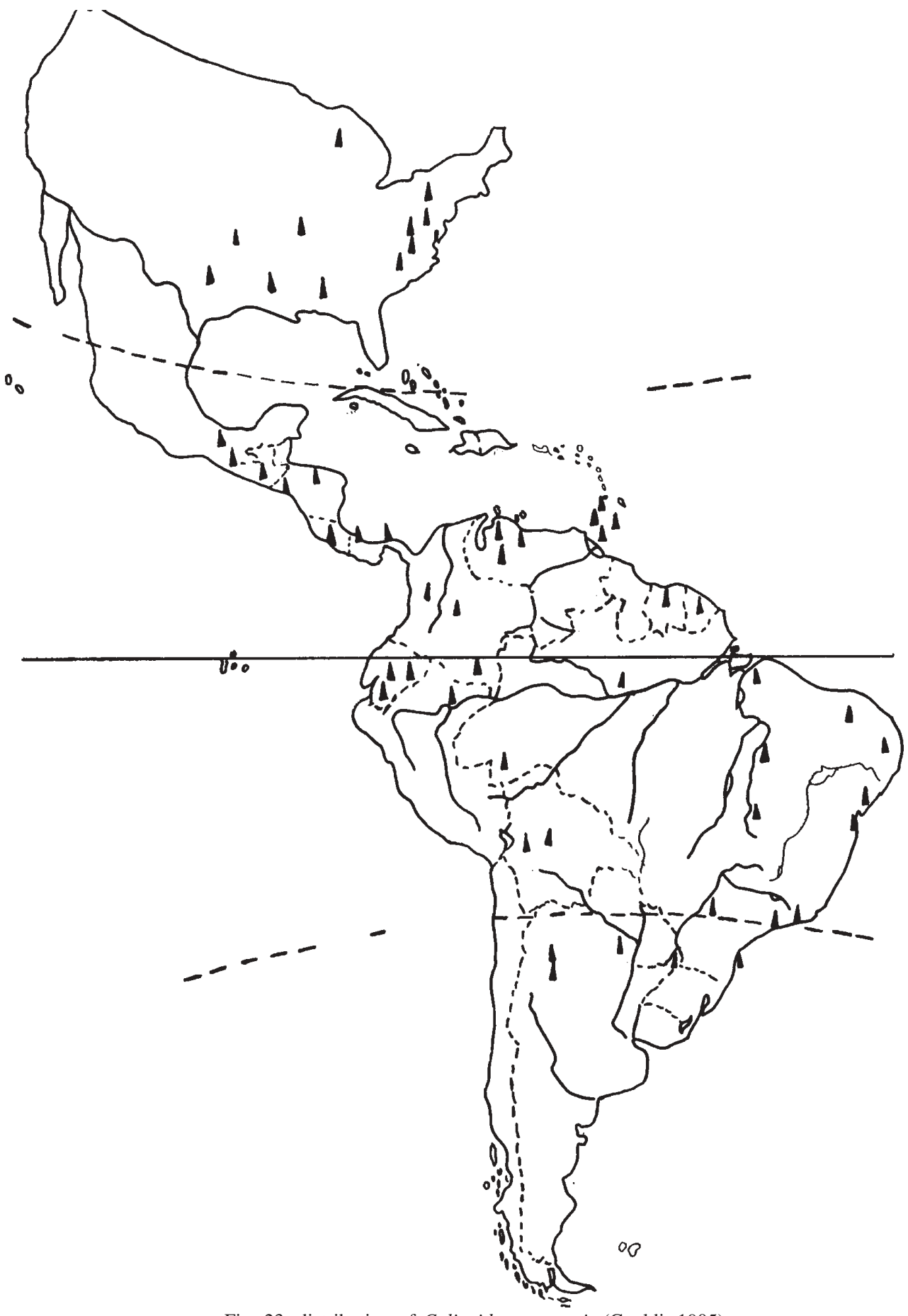

Fig. 23: distribution of Culicoides paraensis (Goeldi, 1905) 
in IOC, as follows: 90 우 우, same data as holotype except 23.IV.2001, 05.VI.2001, 11.VIII.2001, 12.VIII.2001, 22.IX.2001, 13.X.2001, 14.X.2001, 22.II.2002, and 20.IV. 2002; 123 우 우, Aserradero, Distrito de Jamalca, Provincia de Utcubamba, Departamento de Amazonas, PERU, 01.V.2001, 13.V.2001,04.VI.2001, 05.VI.2001, 19.VIII.2001 and 16.IX.2001, A. Gonzales-Perez col., biting human; 5 우, Yungasuyo, Distrito de Lonya Grande, Provincia de Utcubamba, Departamento de Amazonas, PERU, VII.2001, A. Gonzales-Perez col., biting human; 8 우 오, Santa Cruz, Distrito de Jamalca, Provincia de Utcubamba, Departamento de Amazonas, PERU, VII.2001, A. Gonzales-Perez col., biting human; 47 ㅇ ㅇ , El Aliso, Distrito de Cajaruro, Provincia de Utcubamba, Departamento de Amazonas, PERU, 03.XI.2001, A. Gonzales-Perez col., biting human.
Etymology - This species is after the country Peru, where the species was collected.

Discussion - C. peruvianus is a typical member of the subgenus Haematomyidium and, as outlined in the key, can be distinguished from the other species of the paraensis group, by the distal pale spot in cell r5, which gradually extend towards the subapical pale spot and is often joined with it. Also, the equal sized spermathecae with long, stout necks and the high $\mathrm{P} / \mathrm{H}$ ratio $(0.84)$ are all characteristics of the paraensis species group.

\section{DISCUSSION}

The discovery of two new species from the upper reaches of the Amazon basin that are pests of humans suggests that many more species of Culicoides remain to

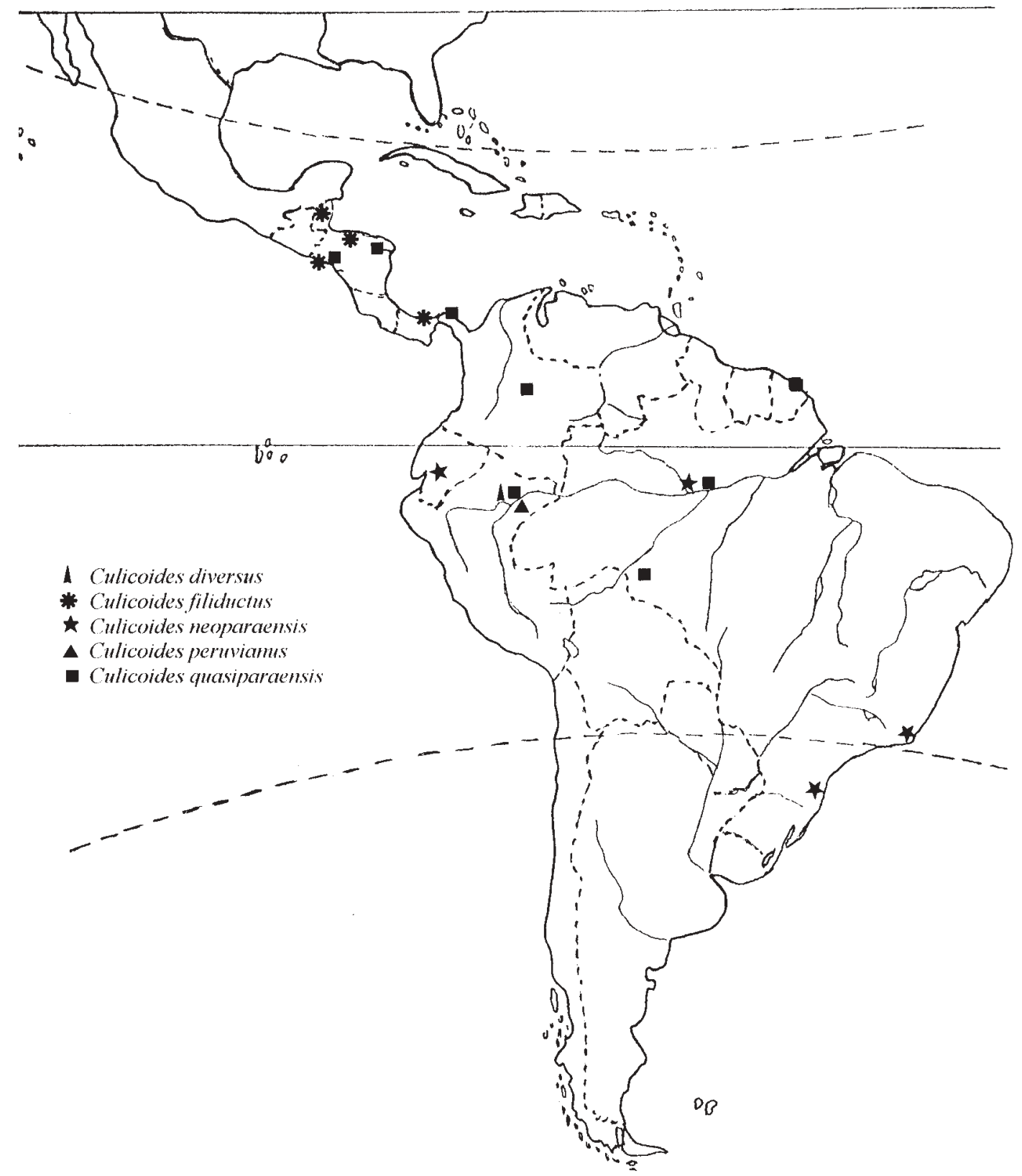

Fig. 24: distribution of Culicoides diversus, C. filiductus, C. neoparaensis, C. peruvianus, and C. quasiparaensis in the Neotropical region 
be described from the Neotropical Region. Numerous areas are poorly collected and it is important that Culicoides, and other genera of Ceratopogonidae, be sampled to obtain a better understanding of the diversity of our region. Furthermore, within the paraensis species group, only the larva and pupa of $C$. paraensis (Murphree \& Mullen 1991, Lamberson et al. 1992) and pupa of C. filiductus (Vitale et al. 1981) are known and the immatures of the remaining species need to be investigated. In addition, species in the paraensis species group all appear to be restricted to lower elevations, suggesting that their speciation has also occurred at these lower altitudes.

\section{ACKNOWLEDGEMENTS}

To Dr Jymni Bardalez, Coordinador de Sanidad Animal de Iquitos, Ministerio de Agricultura, Loreto, Peru, for collecting some of specimens described here. To Drs Art Borkent, William Grogan, and Gustavo Spinelli for reviewing the manuscript.

\section{REFERENCES}

Lamberson C, Pappas CD, Pappas LG 1992. Taxonomy of the tree hole Culicoides (Diptera: Ceratopogonidae) of Eastern North America. Ann Entomol Soc Amer 85: 111-120.

Murphree CS, Mullen GR 1991. Comparative larval morphol- ogy of the genus Culicoides Latreille (Diptera: Ceratopogonidae) in North America with a key to species. Bull Soc Vector Ecol 16: 269-399.

Vitale GC, Wirth WW, Aitken THG 1981. New species and records of Culicoides reared from arboreal habitats in Panama, with a synopsis of the debilipalpis group (Diptera: Ceratopogonidae). Proc Entomol Soc Wash 83: 140-159.

Wirth WW, Blanton FS 1959. Biting midges of the genus Culicoides from Panama (Diptera:Heleidae). Proc US Nat Mus 109: 237-482.

Wirth WW, Blanton FS 1973. A review of the maruins or biting midges of the genus Culicoides (Diptera:Ceratopogonidae) in the Amazon Basin. Amazoniana 4: 405-470.

Wirth WW, Blanton FS 1974. The West Indian sandflies of the genus Culicoides (Diptera:Ceratopogonidae). US Dept Agr Tech Bull 1474: 1-98.

Wirth WW, Felippe-Bauer ML 1989. The Neotropical biting midges related to Culicoides paraensis (Diptera: Ceratopogonidae). Mem Inst Oswaldo Cruz 84 (Suppl. IV): 551565.

Wirth WW, Dyce AL, Spinelli GR 1988. An atlas of wing photographs, with a summary of the numerical characters of the Neotropical species of Culicoides (Diptera: Ceratopogonidae). Contr Am Ent Inst 25: 1-72. 